\title{
The Effect of Organizational Identification on Organizational Commitment
}

\author{
Ertuğrul KÖSE (D) a M. Çağrı PEHLIVANOĞLU iDb \\ a Gübre Fabrikaları Türk A.Ş., İstanbul, Turkey. ertugrulkose73@gmail.com \\ b cpehlivanoglu@yahoo.com
}

\begin{tabular}{|c|c|}
\hline ARTICLE INFO & ABSTRACT \\
\hline $\begin{array}{l}\text { Keywords: } \\
\text { Organizational Identification }\end{array}$ & $\begin{array}{l}\text { Purpose - The aim of this research is to identify the effect of organizational identification on } \\
\text { organizational commitment. }\end{array}$ \\
\hline $\begin{array}{l}\text { Organizational Commitment } \\
\text { Work Experience }\end{array}$ & $\begin{array}{l}\text { Design/methodology/approach - Within the framework of the existing literature, two Likert type } \\
\text { scales were used to measure the conceptual structures. The measurement tools were distributed to } \\
275 \text { participants consisting of white-collar employees working in trade, service and production } \\
\text { companies operating in Istanbul. In total, } 243 \text { respondents filled out the questionnaires, however, } 30\end{array}$ \\
\hline Received 19 May 2020 & of them were evaluated as invalid due to the missing information. Finally, statistical analyses were \\
\hline Revised 18 June 2020 & performed based on the data of 213 respondents. The research was conducted by IBM SPSS 22.0 and \\
\hline Accepted 22 June 2020 & $\begin{array}{l}\text { AMOS } 23.0 \text { software. In addition to the main hypothesis, the relationships between organizational } \\
\text { commitment and demographic variables such as age, status and work experience were investigated } \\
\text { through statistical analysis. }\end{array}$ \\
\hline \multirow[t]{2}{*}{$\begin{array}{l}\text { Article Classification: } \\
\text { Research Article }\end{array}$} & $\begin{array}{l}\text { Findings - It has been concluded that there is a significant, linear, and positive relationship between } \\
\text { two conceptual structures; and organizational identification has an effect on organizational } \\
\text { commitment. On the other hand, no significant relationship was found between organizational } \\
\text { commitment and the demographic variables of age, status, and work experience. }\end{array}$ \\
\hline & $\begin{array}{l}\text { Discussion - Organizational identification was found to be an effective factor in organizational } \\
\text { commitment; and therefore, managers should work on improving the employee identification with } \\
\text { the organizations. The findings are limited to the perceptions of } 213 \text { employees and the sample } \\
\text { consists of employees working in enterprises operating in the trade, production, and service sectors } \\
\text { in Istanbul. The analysis can be expanded further to other industries and employees in the future } \\
\text { studies. }\end{array}$ \\
\hline
\end{tabular}

\section{INTRODUCTION}

Organizational identification and organizational commitment of employees are two important factors in the performance of organizations. For this reason, managers should apply methods and incentives to increase employee identification and commitment in organizations. Organizational identification refers to the situation where both the values and goals of the organization and the individual overlap so that the individual integrates with the organization and sees him or herself as a part of the organization. The individual perceives the organization's success or failure as his or her own success or failure. As the individual defines himself or herself, the organization occupies an important place. Organizational identification is a psychological and cognitive concept; and it is certainly different from organizational commitment. Organizational commitment also considers the interests between the individual and the organization. While organizational commitment is the acceptance of organizational values and beliefs, appropriation prevails beyond acceptance in organizational identification.

Commitment, as a form of concept and understanding, is an emotional form of expression that exists wherever there is a sense of community. It means the state of being dedicated to someone or to an organization. Commitment can be defined as a process that ties the individual to a formation or action. Organizations must meet certain conditions to achieve sustainable success. At this point, it is critical to hire competent employees to the organization, to minimize intention to leave by ensuring employee satisfaction and to establish organizational commitment. The most important indicator of organizational commitment is the coincidence of the employee's goals and values with the goals and values of the organization. An employee who does not adopt the goals and values of an organization cannot be expected to show loyalty to that organization.

\section{Suggested Citation}

Köse, E., Pehlivanoğlu, M. Ç. (2020). The Effect of Organizational Identification on Organizational Commitment, Journal of Business Research-Turk, 12 (2), 2151-2160. 
The relationship between organizational identification and organizational commitment has been examined by various researchers in the literature. However, it has been observed that studies on this subject are limited, particularly in the national literature. This study aims to contribute to the enrichment of knowledge in the literature by investigating the effect of organizational identification on organizational commitment. In addition, the relationships between organizational commitment and demographic variables were examined through the present study. The study includes white-collar employees working in enterprises operating in the trade, production, and service sectors in Istanbul.

\section{LITERATURE REVIEW}

\subsection{Organizational Identification}

Organizational identification can be defined as the integration of an individual by establishing a strong tie with the organization in which he or she is a member. The first model proposal for organizational identification was made by March \& Simon (1958), and then researchers such as Brown (1969), Rotondi (1975), Porter et al. (1979) and Ashforth \& Mael (1989) contributed to the development of the concept. Some researchers considered organizational identification as a dimension of attitudinal organizational commitment, while others argued that it was a separate structure. Ashfort \& Mael suggested that organizational identification is a different and distinct structure from organizational commitment (Riketta, 2005: 359). Mael \& Ashforth (1992: 104) defined organizational identification as "the perception of oneness with or belongingness to an organization, where the individual defines him or herself in terms of the organization(s) in which he or she is a member". According to them, the main difference between identification and commitment is that identification reflects the individuals' own definitions, but there is no such approach in commitment. Identification is a cognitive/perceptual structure that reflects to what extent the organization is included in the concept of self-identity, but commitment is more typically considered as an attitude towards the organization. In parallel with these different conceptualizations, organizational identification is perceived by an individual as a shared destiny with the organization. The distinctiveness of organizational identification and organizational commitment as different conceptual structures has been supported by many theoretical and empirical studies (Riketta, 2005: 374; Van Knippenberg \& Sleebos, 2006: 573; Stinglhamber, et al., 2015: 2).

The concept of organizational identification is based on Tajfel's (1978) social identity theory and Turner's (1985) self-categorization theory. Social identity theory explains social self, group processes and relationships between groups. Self-categorization theory is the continuation of the social identity theory and deals with the classification process in detail as the basis of in-group behavior. Although the two theories have different focus and emphasis, they share many common assumptions and have the same ideological perspective (Hornsey, 2008: 207-208; Gürlek \& Tuna, 2018: 42).

According to the social identity theory, individuals tend to classify themselves and others in different social categories to position and define themselves in the social environment. In line with this theory, some researchers suggest that an organization is the most relevant foci tool for the identification of the individual (Stinglhamber, et al., 2015: 1-2). According to Ashforth \& Mael (1989: 12), organizational identification is a specific form of social identification. Social identification refers to "the perception of being united or belonging to some groups of people". Organizational identification, on the other hand, expresses a person's perception of being or belonging to an organization, and the experience of seeing the organization's success and failure as his or her own success and failure (Mael \& Ashforth, 1992: 103).

Individuals with strong organizational identification perceive the existence of the organization as a factor of defining their self-identity. In addition, individuals with strong organizational identification are proud to be the members of the organization they work for. Therefore, organizational identification refers to a deep psychological phenomenon rather than a superficial relationship. When individuals begin to believe that their organization's values are compatible with their own values, they are likely to develop a strong organizational identification (Ashforth \& Mael, 1989: 35; Ng, 2015: 155).

Organizational identification is a concept related to the level of belonging of the employee to the organization and it takes place when the individual sees the goals of the organization as his / her own. Organizational identification is effective in motivating the employee, displaying extra role behavior, and showing beneficial behavior in the workplace (Xu et. al., 2019: 831). According to the studies in the literature, it has been 
determined that organizational identification positively interacts with attitudes and behaviors of individuals such as emotional commitment, job satisfaction, extra performance, and absenteeism (Klimchak et. al., 2019: 880; Blader et. al., 2017: 20).

\subsection{Organizational Commitment}

Organizational commitment is an important concept for the continuity and achievement of organizations. In the literature, it was observed that there are three main perspectives on organizational commitment. The first one is the attitudinal commitment that arises from the relationship of the individual with the organization and considers the trends towards events, objects, and people. The second one is the behavioral commitment caused by the individual's past behaviors. The third one is the multiple-commitment approach, which is a mixture of attitude and behavioral approach (Brown, 1996: 230-232). Numerous studies have been carried out since 1950s regarding organizational commitment and its dimensions. Many researchers including Kanter (1968), Etzioni (1961), O'Reilly \& Chatman (1986), Reichers (1985), and Allen \& Meyer (1990) evaluated the subject from different perspectives.

Kanter (1968: 500-516) considered organizational commitment as a process that the individual strives to achieve organizational goals and examined commitment in three categories: continuance commitment, compliance commitment and control commitment. Continuance is an individual's approach to maintaining membership in the organization, in considering that the cost of leaving the organization is greater than the cost of staying. Having a benefit in this relationship supports the individual's continuance commitment. In the compliance commitment, harmony, symbols, and ceremonies make the individual fuse with the group come to the fore. Individuals show an interest to ensure their commitment to the organization and belonging to the group. Thus, the commitment of an individual to the group and the relationships in the group increases. Control commitment is the individual's adherence to the organizational norms, leading to a displaying of a positive normative attitude towards the organization. Control commitment occurs when the individual receives the norm, goals, and values of the organization as a guide for showing positive behavior.

Another approach to organizational commitment is Etzioni's model. Etzioni examined organizational commitment in three dimensions: moral commitment, computational commitment, and alienation. According to Etzioni, moral commitment is based on the acceptance, internalization, and identification of the individual. Computational commitment reflects a less intense relationship with the organization than moral commitment. In this type of commitment, individuals compare what they give to the organization and what they get from the organization. This accounting is an exchange-based relationship between the organization and its members Adherence to alienation, on the other hand, expresses a negative approach to the organization in situations where the behavior of individuals is severely limited and there is no alternative. The individual sees the organization as punitive, although he or she is not attached to the organization, he or she is forced to remain a member (Penley \& Gould, 1988: 46-47).

O'Reilly \& Chatman (1986: 493-498) addressed the issue of organizational commitment from the perspective of psychology, and interpreted the concept in three dimensions, which are compliance, identification, and internalization. According to the researchers, the purpose of individuals is to show commitment to the organization to achieve certain rewards and eliminate punishments. Therefore, in compliance commitment, individuals try to adapt and act in harmony to achieve the rewards. The commitment of identification is based on the principle that the individual accepts and identifies the goals and values of the organization. The individual expresses himself or herself, establishes close relationships with the group members and acquires the perspective of the organization. The commitment to internalization harmonizes individual attitudes and behaviors with other members of the organization and integrates them with personal and organizational values.

Reichers (1985) took a holistic view of organizational commitment and developed a multiple commitment approach. This method emphasizes that individuals may show different commitment approaches to their organizations, professions, managers, and colleagues. According to the researcher, one's commitment may differ from another. One individual's organizational commitment may be essentially a function of the perception that the organization is dedicated to launching high-quality products at a reasonable price; while for another person, it may depend heavily on the belief that the organization has humanitarian values for 
employees. The core of the multiple commitment approach is that the internal and external factors of the organization form the basis for multiple commitments (Reichers, 1985: 469-474; Gupta, 2017: 102).

One of the most cited studies in the literature regarding organizational commitment is the approach of Allen \& Meyer (1990). According to them, organizational commitment is "a psychological state that characterizes the employee's relationship with the organization and has implications for the decision to continue or discontinue membership in the organization" (Meyer \& Allen, 1991: 67). This approach consists of three dimensions: affective commitment, continuance commitment and normative commitment. Affective commitment refers to the individual's commitment and integration with the organization. Therefore, the affective dimension of organizational commitment is attitude. In the continuance dimension of commitment, the individual calculates the cost of leaving, takes rational decisions by considering side bets such as working time in the organization and career opportunities. The individual will take an approach to continue as the cost of leaving the organization is high. In the normative commitment dimension, the individual perceives commitment to the organization as a duty and thinks that his or her commitment to the organization is right. Normative commitment is based on the fact that the person believes that he or she has a responsibility towards the organization and feels obliged to stay in the organization. This type of commitment is based on virtue and moral emotions (Allen \& Meyer, 1990: 1-15; Aranki et. al., 2019: 140).

Although researchers approached the concept of organizational commitment with different dimensions, all of them are parallel to each other. Generally, Allen \& Meyer's three-component organizational commitment approach (affective, continuance and normative commitment) is a commonly preferred model in literature in terms of content. Organizational commitment of individuals can be based on different reasons and can occur in different degrees. Individuals may take an approach to organizations within the framework of affective commitment, continuance commitment, or normative commitment, or can exhibit a mixture approach of all three types of commitment within diversified degrees. In this study, the concept of organizational commitment was addressed within the framework of Allen \& Meyer (1990)'s three-dimensional organizational commitment approach.

\section{RESEARCH METHODOLOGY}

This research is a quantitative study. Research data was gathered by means of questionnaires. The study was carried out to examine the relationships between organizational identification and organizational commitment. Two scales were used to measure the dimensions of the research. Both scales are five-point Likert type scales which are previously tested by various researchers.

The research was conducted by IBM SPSS 22.0 and AMOS 23.0 software. To determine the construct validity of the scales, explanatory factor analysis (EFA) and confirmatory factor analysis (CFA) was performed; and to specify the reliability of the scales, composite reliability, and Cronbach $\alpha$ values were calculated. SPSS was used for the analysis of descriptive statistics, explanatory factor analysis and hypothesis testing; and AMOS software was used for confirmatory factor analysis. Regression analysis was used to test relationship between the predictor and outcome variables. T-test was used to determine the relationships between organizational identification and status groups, and ANOVA was used for organizational identification and age, education level and work experience groups.

\subsection{Hypotheses of The Research}

Organizational Identification Perception (OIP) is the predictor variable and Organizational Commitment (OC) is the outcome variable. The main hypothesis of the study was determined as follows: "Organizational identification perception positively affects organizational commitment". In addition, the respondents OC scores with respect to status (manager / non-manager), work experience (1-5 years, 6-10 years, 11-15 years, 16-20 years, +21 years) and age (18-29 years old, 30-39 years old, 40-49 years old, 50-59 years old, +60 years old) were investigated. Therefore, the second hypothesis of the study was as follows: "There is a significant difference in the organizational commitment average scores with respect to status groups". The third hypothesis of the study was as follows: "There is a significant difference between the organizational commitment average scores of the work experience level groups". The fourth hypothesis of the study was as such: "There is a significant difference between the organizational commitment average scores of the age level groups". 


\subsection{Measures and Sampling}

The measurement tools consist of six demographic questions and two scales. The first measurement tool is a scale with 6 items adopted from Mael \& Ashforth (1992) measuring Organizational Identification (OIP) having only one dimension; the second measurement tool is a scale with 18 items adopted from Meyer \& Allen (1991) measuring Organizational Commitment (OC) and has three dimensions. The dimensions of the organizational commitment scale are as follows: Affective commitment, continuance commitment and normative commitment (Meyer et. al., 1993: 544). All the items are collected on a Likert-type 5-level measurement tool. The levels of the scales are as follows: (1) strongly disagree, (2) disagree, (3) neither agree nor disagree, (4) agree, (5) strongly agree.

The universe of the research consists of white-collar employees working in the production, trade, and service sectors in Istanbul. Power analysis technique was used to determine the sample size of the research. As the result of this analyses, it was decided that the questionnaires should be distributed to at least 239 respondents within the 95\% confidence interval. To reach this target, 275 questionnaires were distributed between JuneOctober 2019 by convenience sampling method to the respondents working at various enterprises. Finally, 213 of the questionnaires were found to be valid for the statistical analysis. The distribution of the sample is as follows: 161 males, 52 females; 94 managers, 119 non-managers; 85 of them are working at service companies, 33 trade companies, 95 production companies; $89 \%$ of the sample have at least a graduate degree; $20 \%$ of the sample is between $18-29$ years old, $41 \%$ is between $30-39$ years old, $26 \%$ is between $40-49$ years old, $10 \%$ is between $50-59$ years old, $3 \%$ is +60 years old; $20 \%$ of the respondents have $0-5$ years of work experience, $17 \%$ have $6-10$ years, $22 \%$ have $11-15$ years, $16 \%$ have $16-20$ years, and $25 \%$ have +21 years.

\subsection{Analyses of Dimensionality, Validity and Reliability}

Prior to factor analysis, Kaiser Meyer Olkin (KMO) and Barlett sphericity test statistics were calculated to determine the adequacy and suitability of the sample. In this test, the KMO coefficient must be greater than 0.60 and the Barlett test statistic value should be significant (Beavers et. al., 2013: 4). As a result of the analysis, KMO test result of organizational identification scale was 0.846 with significant Barlett statistical test result $(p$ $=0.00) ; \mathrm{KMO}$ test result of organizational commitment scale was 0.808 with significant Barlett statistical test result $(p=0.00)$. Within the framework of these findings, the sample was enough and appropriate to proceed to forward analysis.

To examine the factorial structure of the scales, EFA is conducted. All the items were involved in the analysis. Only variables that have a value of 0.40 and above and have more than 0.20 differences between each other were included in the final scales. In the organizational commitment scale, 14 out of 18 of the items passed the threshold levels, whereas in the organizational identification scale, all the items passed the threshold levels.

After determining the factorial structure, reliability analysis was performed for the measurement tools. One of the methods used for reliability analysis is the internal consistency approach. Cronbach's alpha reliability is the mostly used method to determine the internal consistency reliability. In the study, reliability coefficients for both measurement tools were calculated separately. The Cronbach's alpha values should be at least $\alpha \geq 0$. 60 (Gliem \& Gliem, 2003: 87). The analysis in Table 1 showed that reliability of all the scales and dimensions were found to be higher than the expected level.

Table 1. Cronbach's Alpha values for Scales and Dimensions

\begin{tabular}{lcc}
\hline \hline Scales and Dimensions & Number of items & Cronbach's Alpha \\
\hline Organizational Identification & 6 & 0.832 \\
Organizational Commitment & 14 & 0.825 \\
Affective Commitment & 4 & 0.763 \\
Continuance Commitment & 5 & 0.721 \\
Normative Commitment & 5 & 0.749 \\
\hline
\end{tabular}

In the next step, CFA was applied to specify the convergent validity of the scales. Therefore, the goodness of fit statistics, Average Variance Extracted (AVE) and Composite Reliability (CR) values are investigated. In Table 2 and Table 3 AVE values, composite reliability and correlation coefficient values are indicated. All AVE (above 0.50 ) and CR (above 0.70 ) values were found beyond the threshold levels specified in the literature 
(Yaşlığlu, 2017: 82; Ahmad et. al., 2016: 3). The goodness of fit statistics is interpreted in the context of the specified value ranges given in the literature (Bagozzi \& Yi, 2012: 28). Chi-square/Degrees of Freedom $=\chi 2 / \mathrm{df}$ $<3$ (valid for both scales OC 2.91; OIP 2.34), RMSEA $\leq 0.06$ (valid for both scales OC 0.051; OIP 0.043), CFI $\geq 0.95$ (valid for both scales OC 0.96; OIP 0.97), GFI $\geq 0.95$ (valid for both scales OC 0.96; OIP 0.98) and SRMR $<0.08$ (valid for both scales OC 0.71; OIP 0.62). Confirmatory factor analysis showed that both scales are in good fit and these results confirmed the convergent validity of the scales.

Table 2. CR, Correlation Coefficient and AVE values for OIP and OC

\begin{tabular}{lccccc}
\hline \hline Dimensions & Number of items & CR & AVE & 1 & 2 \\
\hline 1. Organizational Identification & 6 & 0.973 & 0.739 & & \\
2. Organizational Commitment & 14 & 0.843 & 0.685 & 0.580 & \\
\hline
\end{tabular}

Table 3. CR, Correlation Coefficient and AVE values for OC

\begin{tabular}{lcccccc}
\hline Dimensions & Number of items & CR & AVE & 1 & 2 & 3 \\
\hline 1. Affective Commitment & 4 & 0.937 & 0.722 & & & \\
2. Continuance Commitment & 5 & 0.933 & 0.645 & 0.255 & & \\
3. Normative Commitment & 5 & 0.942 & 0.642 & 0.437 & 0.465 & \\
\hline
\end{tabular}

\subsection{Tests of Hypotheses}

The main hypothesis of the study was determined as organizational identification perception positively affects organizational commitment. Simple linear regression analysis was used to determine the effect of the perception of organizational identification on organizational commitment. Prior to the analysis, the assumptions of linearity, multivariate normality, homoscedasticity, no autocorrelation, and no multicollinearity which are the prerequisites of simple linear regression analysis, were tested and found to pass all criteria. According to the linear regression analysis of the main research hypothesis, the predictor variable Organizational Identification Perception scale scores explain $34 \%$ of the variance in the dependent variable Organizational Commitment scale scores $\left(R^{2}=0.336, F(1,211)=106.932, p=0.00<0.05\right)$. The null hypothesis was rejected and $H_{1}$ was accepted. As shown in Table 4 and Table 5, the result designates a significant and positive relationship between organizational identification perception and organizational commitment.

Table 4. Model Summary

\begin{tabular}{ccccc}
\hline \hline Model & $R$ & $\begin{array}{c}R \\
\text { Square }\end{array}$ & Adjusted R Square & $\begin{array}{c}\text { Std. Error of the } \\
\text { Estimate }\end{array}$ \\
\hline 1 & $0,580^{\text {a }}$ & 0,336 & 0,333 & 0,568 \\
\hline
\end{tabular}

a. Predictors: (Constant), OIP

Table 5. ANOVAa

\begin{tabular}{llccccc}
\hline \hline & Model & Sum of & $d f$ & Mean & F & Sig. \\
& Squares & & Square & & \\
\hline \multirow{2}{*}{1} & Regression & 34,489 & 1 & 34,489 & 106,932 & $0,000^{\mathrm{b}}$ \\
& Residual & 68,054 & 211 & 0,323 & & \\
& Total & 102,542 & 212 & & & \\
\hline
\end{tabular}

a. Dependent Variable: OC

b. Predictors: (Constant), OIP

In the second hypothesis, the respondents' OC scores with respect to status (manager / non-manager) groups were investigated. T-test was conducted to determine whether there is a significant difference between the organizational commitment average scores of the groups according to the status variable. As a result of T-test analysis, it has been observed that there was not any significant difference $(p=0.927)$ between the OC scores of status groups. Therefore, $\mathrm{H}_{2}$ was rejected. 
Table 6. T-test for Status groups

\begin{tabular}{lccccc}
\hline \hline \multicolumn{1}{c}{ Variance } & $\mathrm{t}$ & $d f$ & Sig. (2-tailed) & $\mathrm{F}$ & Sig. \\
\hline Equal variances assumed & 1,694 & 211 & 0,092 & 0,008 & 0,927 \\
Equal variances not assumed & 1,697 & 200,949 & 0,091 & & \\
\hline
\end{tabular}

In the third hypothesis, the respondents' OC scores with respect to the work experience (1-5 years, 6-10 years, 11-15 years, 16-20 years, +21 years) groups were investigated. One-way ANOVA analysis was used to determine whether there is a significant difference between the organizational commitment average scores of the groups according to the work experience variable. Prior to the analyses, the assumptions of ANOVA which are independence of cases, normality and homoscedasticity, were tested and found to be fulfilled. As a result of one-way ANOVA analysis, it has been observed that there is not a significant difference $(p=0.842)$ between the OC scores of work experience groups. Therefore, $H_{3}$ was rejected.

Table 7. ANOVA for Work Experience groups

\begin{tabular}{lccccc}
\hline \multicolumn{1}{c}{ OC } & $\begin{array}{c}\text { Sum of } \\
\text { Squares }\end{array}$ & $d f$ & $\begin{array}{c}\text { Mean } \\
\text { Square }\end{array}$ & F & Sig. \\
\hline Between Groups & 0,691 & 4 & 0,173 & 0,353 & 0,842 \\
Within Groups & 101,852 & 208 & 0,490 & & \\
Total & 102,542 & 212 & & & \\
\hline
\end{tabular}

In the fourth hypothesis, the respondents' OC scores with respect to age (18-29 years, 30-39 years, $40-49$ years, 50-59 years, +60 years) groups were investigated. One-way ANOVA analysis was used to determine whether there is a significant difference between the organizational commitment average scores of the groups by age variable. Prior to the analyses, the assumptions of ANOVA were tested and found to be fulfilled. As a result of one-way ANOVA analysis, it has been observed that there does not exist a significant difference $(p=0.249)$ between the OC scores of age groups. Therefore, $H_{4}$ was rejected. Post Hoc test was not applied since there was no significant difference between the organizational commitment average scores of groups regarding age and work experience.

Table 8. ANOVA for Age groups

\begin{tabular}{lccccc}
\hline \multicolumn{1}{c}{ OC } & $\begin{array}{c}\text { Sum of } \\
\text { Squares }\end{array}$ & $d f$ & $\begin{array}{c}\text { Mean } \\
\text { Square }\end{array}$ & F & Sig. \\
\hline Between Groups & 2,611 & 4 & 0,653 & 1,359 & 0,249 \\
Within Groups & 99,931 & 208 & 0,480 & & \\
Total & 102,542 & 212 & & & \\
\hline
\end{tabular}

\section{CONCLUSION}

This study aimed to investigate the effect of organizational identification on organizational commitment. As the result of the research, it was determined that there is a significant, positive, and linear relationship between the organizational identification perception of employees and organizational commitment. This result is in line with the findings in the literature (İyigün, 2015: 186; Ahmad \& Islam, 2018: 123; Stinglhamber, et al., 2015: 14-15).

There was not any significant relationship found between organizational commitment and demographic variables such as status, work experience and age. In terms of status, research findings have shown that employee's organizational commitment is not related to whether being a manager or not. There are also similar studies in the literature where this relationship is not significant (see for example, Baysal et. al., 2014: 148; Yeşilkaya, 2015: 192-193). This finding could be interpreted as being a manager might not change the sense of commitment associated with the organization. In terms of work experience, the relationship between organizational commitment and work experience has been not significant for this research. In the literature, although the studies that this relationship is positive are predominant, there are also studies where the relationship is not significant (see for example, Yılmazer, 2010: 247; Fettahlıoğlu \& Tatlı, 2015: 131-133; Babadağ, 2015: 326-327). In terms of age, the relationship between organizational commitment and different levels of age has been not significant for this research and there are also similar studies in the literature where 
E. Köse - M. Ç. Pehlivanoğlu 12/2 (2020) 2151-2160

this relationship has been found to be not significant (see for example, Visanh \& Xu, 2018: 813; Şener, 2013: 56; Yeşilkaya, 2015: 192-193). In the literature, it is observed that the findings between the demographic variables such as status, age, work experience groups and organizational commitment varies from research to research, depending on the participating audience and questionnaires.

\section{DISCUSSION AND IMPLICATIONS}

Since organizational identification is an effective factor in organizational commitment, this research has several recommendations to managers that could help to improve employee identification with the organizations. First, all the members of the organization should be encouraged to participate in decisionmaking process. Second, an open communication policy should be followed throughout the organization and in this way, individuals could be able to share their opinions and suggestions easily. Finally, managers should take into consideration the principle of transparency in all decisions and implementation of processes.

All the findings on demographic variables are only valid for this research and different researchers might find different results. The research has some limitations and the results need to be evaluated within this framework. Research findings are limited to the perceptions of 213 employees. Another limitation is that the scope of research consists of employees working in enterprises operating in the trade, production, and service sectors in Istanbul. By expanding the sample to other industries, more comprehensive analysis can be conducted.

\section{REFERENCES}

Ahmad, R., \& Islam, T. (2018). Relationships between corporate social responsibility, work engagement and organizational commitment: explanatory role of organizational identification. Journal of Behavioural Sciences, 28(2), 112-130.

Ahmad, S., Zulkurnain, N. N., \& Khairushalimi, F. I. (2016). Assessing the validity and reliability of a measurement model in structural equation modeling (SEM). British Journal of Mathematics \& Computer Science, 15(3), 1-8.

Allen, N. J., \& Meyer, J. P. (1990). The measurement and antecedents of affective, continuance and normative commitment to the organization. Journal of Occupational Psychology, 63(1), 1-18.

Aranki, D. H., Suifan, T. S., \& Sweis, R. J. (2019). The relationship between organizational culture and organizational Commitment. Modern Applied Science, 13(4), 137-154.

Ashforth, B. E., \& Mael, F. (1989). Social identity theory and the organization. Academy of Management Review, 14(1), 20-39.

Babadağ, M. (2015). Demografik faktörlerin örgütsel bağlllığa etkisi: Bir uygulama. Cankiri Karatekin University Journal of Institute of Social Sciences, 6(2), 313-332.

Bagozzi, R. P., \& Yi, Y. (2012). Specification, evaluation, and interpretation of structural equation models. Journal of the Academy of Marketing Science, 40(1), 8-34.

Baysal, İ. A., Baysal, G., Aksu, G., \& Aksu, N. (2014). Presenteeism (işte varolmama sorunu) ile örgütsel bağlılık arasındaki ilişki: Adnan Menderes Üniversitesi akademik personeli üzerinde bir uygulama. Electronic Journal of Vocational Colleges, BÜROKON Özel Sayısı, Ağustos, 134-152.

Beavers, A. S., Lounsbury, J. W., Richards, J. K., Huck, S. W., Skolits , G. J., \& Esquivel, S. L. (2013). Practical considerations for using exploratory factor analysis in educational research. Practical Assessment, Research \& Evaluation, 18(6), 1-13.

Blader, S. L., Patil, S., \& Packer, D. J. (2017). Organizational identification and workplace behavior: More than meets the eye. Research in Organizational Behavior, 37, 19-34.

Brown, R. B. (1996). Organizational commitment: Clarifying the concept and simplifying the existing construct typology. Journal Vocational Behavior, 49, 230-251.

Brown, M. (1969). Identification and some conditions of organizational involvement. Administrative Science Quarterly, 14, 346-355. 
Etzioni, A.(1961). A comparative analysis of complex organizations. New York: Free Press.

Fettahlığlu, Ö. O., \& Tatlı, H. S. (2015). Örgütsel bağlılık ve farklılıkların yönetimi algılamaları arası ilişkilerin saptanmasında demografik farklılıklara yönelik inceleme. KSU Journal of Social Sciences, 12(2), 119-140.

Gliem, J. A., J. A., \& Gliem, R. R. (2003). Calculating, interpreting, and reporting cronbach's alpha reliability coefficient for likert-type scales. Midwest Research to Practice Conference in Adult, Continuing, and Community Education (pp. 82-88). Columbus: The Ohio State University.

Gupta, M. (2017). Corporate social responsibility, employee-company identification, and organizational commitment: mediation by employee engagement. Current Psychology, 36, 101-109.

Gürlek, M., \& Tuna, M. (2018). Sosyal kimlik teorisi açısından örgütsel özdeşleşmenin teorik temelleri. Yönetim, Ekonomi ve Pazarlama Araştırmalari Dergisi, 2(3), 39-48.

Hornsey, M. J. (2008). Social identity theory and self-categorization theory: A historical review. Social and Personality Psychology Compass, 2(1), 204-222.

İyigün, Ö. (2015). Örgütsel özdeşleşmenin örgüte bağlllık üzerindeki etkisinde örgüte tutkunluğun aracilık etkisi: serbest muhasebeci ve mali müşavirler üzerine bir araştırma. "İ̧̧, GüÇ" Endüstri İlişkileri ve İnsan Kaynakları Dergisi, 17(1/4), 171-192.

Kanter, R. M. (1968). Commitment and social organization: A study of commitment mechanisms in utopian communities. American Sociology Review, 33(4), 498-517.

Klimchak, M., Ward, A.-K., Matthews, M., Robbins, K., \& Zhang, H. (2019). When does what other people think matter? the influence of age on the motivators of organizational identification. Journal of Business and Psychology, 34, 879-891.

Mael, F., \& Ashforth, B. E. (1992). Alumni and their alma mater: A partial test of the reformulated model of organizational identification. Journal of Organizational Behavior, 13, 103-123.

March, J., and Simon, H. (1958). Organizations. New York: John Wiley.

Meyer, J.P., Allen, N.J., \& Smith C. A. (1993). Commitment to organizations and occupations: Extension and test of a three-component conceptualization. Journal of Applied Psychology, 78 (4), 538-551.

Meyer, J. P., \& Allen, N. J. (1991). A three-component conceptualization of organizational commitment. Human Resource Management review, 1(1), 61-89.

$\mathrm{Ng}$, T. W. (2015). The incremental validity of organizational commitment, organizational trust, and organizational identification. Journal of Vocational Behavior, 88, 154-163.

O'Reilly III, C., \& Chatman, J. (1986). Organizational commitment and psychological attachment: The effects of compliance, identification and internalization on prosocial behavior. Journal of Applied Psychology, 71(3), 492-499.

Penley, L. E., \& Gould, S. (1988). Etzioni's model of organizational involvement: a perspective for understanding commitment to organizations. Journal of Organizational Behavior, 9(1), 43-59.

Porter, L. W., Mowday, R. T., \& Steers, R. M. (1979). The measurement of organizational commitment. Journal of Vocational Behavior, 14(2), 224-247.

Reichers, A. E. (1985). A review and reconceptualization of organizational commitment. The Academy of Management Review, 10(3), 465-476.

Riketta, M. (2005). Organizational identification: A meta-analysis. Journal of Vocational Behavior, 66, 358-384.

Rotondi, T .. Jr. (1975) Organizational identification: issues and implications. Organizational Behavior and Human Performance, 13, 95-109. 
Stinglhamber, F., Marique, G., Caesens, G., Desmette, D., Hansez, I., Hanin, D., \& Bertrand, F. (2015). Employees' organizational identification and affective organizational commitment: An integrative approach. PLoS ONE, 10(4), 1-23.

Şener, O. (2013). Genel kamu liselerinde psikolojik yıldırma ve örgütsel bağlllık ilişkisi. Karatekin Edebiyat Fakültesi Dergisi (KAREFAD), 1(1), 47-64.

Tajfel, H. (1978). Interindividual behavior and intergroup behavior. In H. Tajfel (Ed.), Differentiation between social groups (pp. 27-60). London: Academic Press.

Turner, J. C. (1985). Social categorization and the self-concept: A social cognitive theory of group behavior. In E. J. Lawler (Ed.), Advances in group processes (Vol. 2, pp. 77-122). Greenwich, CT: JAI Press.

Van Knippenberg , D., \& Sleebos, E. (2006). Organizational identification versus organizational commitment: Self-definition, social exchange, and job attitudes. Journal of Organizational Behavior, 27, 571-584.

Visanh, P., \& Xu, H. (2018). Factors affecting organizational commitment of employee's of Lao development bank. Sociology International Journal, 2(6), 809-818.

Xu, Q., Zhang, G., \& Chan, A. (2019). Abusive supervision and subordinate proactive behavior: Joint moderating roles of organizational identification and positive affectivity. Journal of Business Ethics, 157, 829-843.

Yaşlıŏ̆lu, M. M. (2017). Sosyal bilimlerde faktör analizi ve geçerlilik: keşfedici ve doğrulayıcı faktör analizlerinin kullanılması. Istanbul University Journal of the School of Business, 46 (Special Issue), 74-85.

Yeşilkaya, M. (2015). Örgütsel bağlllık düzeyinin demografik özellikler açısından gösterdiği farklılıkların istatistiksel yöntemlerle incelenmesi. Kafkas Üniversitesi İktisadi ve İdari Bilimler Dergisi, 185-194.

Yılmazer, A. (2010). Örgütsel bağlılık ve ekstra rol davranışı arasındaki ilişkiler: İmalat sektöründe bir araştırma. Eskişehir Osmangazi Üniversitesi İ̈BF Dergisi, 5(2), 236-250. 